\title{
Influence of geographic distance and genetic dissimilarity among clones on flowering synchrony in a Teak (Tectona grandis Linn. f) clonal seed orchard
}

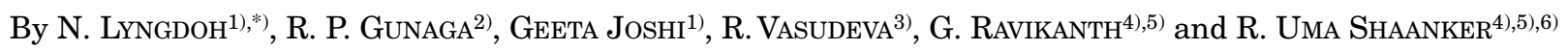

(Received $6^{\text {th }}$ January 2011)

\begin{abstract}
Influence of genetic dissimilarity among teak (Tectona grandis Linn. f.) clones on flowering synchrony was studied in a Clonal Seed Orchard (CSO) of teak in Karnataka, Southern India. Flowering phenology was monitored for all the 24 teak clones of the CSO and flowering synchrony between clones was assessed adopting a novel 'overlap index'. Genetic dissimilarity among these clones was assessed adopting DNA based ISSR (Inter Simple Sequence Repeats) analysis. Large variation in the time of 'flower initiation' and of 'peak flowering initiation' was observed among the clones belonging to diverse sources, suggesting large asynchronous flowering. Cluster analysis based on ISSR marker indicated that the clones originating from a same source clustered together and there was a clear segregation based on their origin. Correlation analysis revealed a significant negative association between the average Jaccards's dissimilarity index between pairs of clones and average peak flowering overlap index. Clones from geographically diverse regions had high genetic dissimilarity and also showed high flowering asynchrony within them.
\end{abstract}

Key words: Provenance effect, genetic markers, flowering phenology, genetic distance.

\section{Introduction}

One of the main objectives of a tree improvement programme is the production of genetically improved seed crops, which could be produced in operational quantities by adopting seed orchard approach (ANDERSSON, 1960). A seed orchard is a collection of phenotypically superior and diverse individuals of a species, which are managed to produce a genetically superior seed crop through the process of open pollination (Askew, 1986).

Flowering synchrony among constituent clones is crucial among the factors that influence seed production in

\footnotetext{
1) Tree Improvement and Propagation Division, Institute of Wood Sciences and Technology, $18^{\text {th }}$ Cross Malleswaram, Bangalore.

2) College of Forestry, Dr BSKKV, Dapoli 415 712, India.

$\left.{ }^{3}\right)$ Department of Forest Biology and Tree Improvement, College of Forestry, Sirsi, 581401, Karnataka, India.

${ }^{4}$ ) School of Ecology and Conservation, University of Agricultural Sciences, Bangalore 560065, India.

5) Ashoka Trust for Research in Ecology and the Environment, Royal Enclave, Srirampura, Jakkur Post, Bangalore-560064, India.

${ }^{6}$ ) Department of Crop Physiology, University of Agricultural Sciences, Bangalore 560065, India.

*) Corresponding author: N. LyNGDOH. College of Horticulture and Forestry, Central Agricultural University, Pasighat, Arunachal Pradesh, India, Pin: 791 102. Phone No. +919612459793. E-Mail: lyng $\underline{\text { doh@gmail.com }}$
}

a clonal seed orchard (CSO), since it directly influences the exchange of gametes among clones. Complete flowering synchrony among clones facilitates panmictic equilibrium, which is one of the basic assumptions for an idealized seed orchard. However, studies on numerous temperate coniferous species have shown that this is seldom true. For instance, non-synchrony among the constituent clones of a seed orchard has been reported by EL-KASSABY et al. (1988) in Douglas-fir (Pseudotsuga menziesii); in Sitka spruce (Picea sitchensis) by ELKASSABY and REYNOLDS (1990); in radiata pine (Pinus radiata) by GRIFFIN (1984); in black pine (Pinus nigra) by Matziris (1994); in loblolly pine (Pinus taeda) by Askew, (1988) and AsKew and Blush (1990). Amongst tropical species, early and late flowering clones have been identified in CSO of Eucalyptus grandis (CHAIX et al., 2007) and Tectona grandis (RADHAMANI et al., 1998; PALUPI and OwEN, 1998; GunAGA et al., 1999). Deviation from panmictic equilibrium through incomplete flowering synchrony is expected to reduce the efficiency of seed orchards through mating among closely-related individuals. Clonal differences in pollen release and female receptivity also has a profound effect on the genetic composition of progeny (ERIKSSON et al., 1973; JONSSON et al., 1976; REILlY et al., 1982).

Physical and climatic factors are known to cause annual variations in flowering behaviour of clones in an orchard. For instance, ALIzOTI et al. (2010) have recorded spatial and temporal variations in flowering behaviour of black pine (Pinus nigra) as a response to changing climatic conditions. On the other hand, NIKKANEN (2001) has shown in Norway spruce (Picea abies) that reproductive phenological events can be influenced by differences in spacing between grafts and physical factors such as direction and gradient of a slope where grafts are planted. Yet, in a large number of species strong genetic control has been invoked to explain the flowering behaviour among clones in an orchard (Matziris, 1994; VASUdeVA et al., 2000). Primarily, reproductive phenology is a highly genetically influenced trait and clones tend to retain the reproductive phenology of their original provenance (VASUDEVA et al., 2000). ELKASSABY et al. (1988) have attributed large differences in phenological behaviour among clones of Douglas fir to the diverse origin of clonal material assembled in the orchard. Similarly, clonal differences in flowering phenology were smaller in a CSO of Norway spruce established using clones originating from neighboring geographic areas with similar climatic conditions (NIKKANEN, 2001). Therefore it is generally assumed that level of genetic divergence among the constituent clones in an 
orchard due to their diverse origin could determine the level of flowering asynchrony among them (LYNGDOH, 2010). However, there has been no earlier attempt to quantitatively test this hypothesis since this requires carefully monitored data on phenology of individual clones as well as data on their genetic relatedness, assessed adopting robust molecular marker techniques. Further, lack of a quantitative index that summarily characterizes flowering synchrony of a clone with the rest of the clones in an orchard, was also a stumbling block, until it was developed by GuNAGA and VASUDEVA (2009).

We hypothesized that the levels of flowering synchrony within an orchard is dependent on the average genetic relationship among its constituent clones. To test this hypothesis we monitored the flowering phenology of 24 clones of teak (Tectona grandis L. f.) in a 21year-old clonal seed orchard and estimated the genetic dissimilarity among the clones adopting a DNA based ISSR (Inter Simple Sequence Repeats) marker employing 10 primers. Subsequently, the two parameters were subjected to a correlation analysis.

\section{Material and Methods}

\subsection{Study site for flowering phenology}

Investigation on flowering phenology of teak clones was undertaken in a teak CSO established at Manchikere hamlet in Uttara Kannada District, Karnataka, southern India. This CSO was established in 1980 using 24 superior teak clones originating from three broad geographic regions of Karnataka; thirteen clones derived from Northern zone, four from Central and seven from Southern zone (Table 1 and 2; Fig. 1).

Table 1. - Passport data of teak clones of Manchikere Clonal Seed Orchard (CSO), Karnataka, India.

\begin{tabular}{|c|c|c|c|c|}
\hline $\begin{array}{l}\text { Sl. } \\
\text { No. }\end{array}$ & Clone I.D. & $\begin{array}{c}\text { Teak growing } \\
\text { zone in } \\
\text { Karnataka } \\
\text { State }\end{array}$ & $\begin{array}{l}\text { Forest Division } \\
\text { from which the } \\
\text { teak clone was } \\
\text { identified }\end{array}$ & $\begin{array}{c}\text { Forest Range } \\
\text { from which the } \\
\text { teak clone was } \\
\text { identified }\end{array}$ \\
\hline 1 & MyHaD1 & North & Haliyal & Barchi \\
\hline 2 & $\mathrm{MyHaD2}$ & ---do--- & ---do--. & ----do--- \\
\hline 3 & $\mathrm{MyHaD} 3$ & ---do--- & ---do--- & ---do--- \\
\hline 4 & MyHaD4 & ---do--- & ---do--- & ---do--- \\
\hline 5 & MyHaV1 & ---do--- & ---do--- & Gundvamoli \\
\hline 6 & $\mathrm{MyHaV3}$ & ---do--- & ---do--- & ---do--- \\
\hline 7 & MyHaV4 & ---do--- & ---do--- & ---do--- \\
\hline 8 & MyHaV5 & ---do--- & ---do--- & Virnoli \\
\hline 9 & MyHaV6 & ---do--- & ---do--- & ---do--- \\
\hline 10 & MyHaV7 & ---do--- & ---do--- & ---do--- \\
\hline 11 & MySA1 & Central & Shimoga & Arasake \\
\hline 12 & MySA2 & ---do--- & ---do--- & ---do--- \\
\hline 13 & MySS2 & ---do--- & ---do--- & Sacrebyle \\
\hline 14 & MyHuT1 & South & Hunsur & Tithimathi \\
\hline 15 & MyHuT2 & ---do--- & ---do--- & ---do--- \\
\hline 16 & MyHuT3 & ---do--- & --do--- & ---do--- \\
\hline 17 & MyHuT6 & ---do--- & ---do--- & ---do--- \\
\hline 18 & MyHuT7 & ---do--- & ---do--- & ---do--- \\
\hline 19 & MyHuT8 & ---do--- & ---do--- & ---do--- \\
\hline 20 & MyBL1 & Central & Lakavalli & Bhadravati \\
\hline 21 & MyHaK1 & North & Haliyal & Kulagi \\
\hline 22 & MyHaK2 & ---do--- & ---do--- & ---do--- \\
\hline 23 & $\mathrm{MyHaK} 3$ & ---do--- & ---do--- & ---do--- \\
\hline 24 & MyMK3 & South & Mysore & Kakanakote \\
\hline
\end{tabular}

Table 2. - Climatic parameters of regions where plus trees of teak were selected.

\begin{tabular}{|l|c|c|}
\hline Regions & $\begin{array}{c}\text { Annual Mean } \\
\left.\text { Temperature } \mathbf{~}^{\mathbf{0}} \mathbf{C}\right)\end{array}$ & $\begin{array}{c}\text { Annual Precipitation } \\
(\mathbf{m m})\end{array}$ \\
\hline South & 23.5 & 1573 \\
\hline Central & 23.8 & 2374 \\
\hline North & 25.0 & 2066 \\
\hline
\end{tabular}

The planting had been done adopting Completely Randomized Design with unequal replications over an area of 4 ha.

Plus trees were earlier selected through a rigorous selection procedure involving standard check trees some time during 1970's through an initiative of state forest department and the Forest Research Institute (FRI), Dehra Dun, India (RAMACHANDRA et al., 2001). Each clone was given a unique number indicating the forest range from which the mother tree was selected and were deployed as clone in seed orchards as well as maintained in a clonal bank. The selection was done over a wide geographic range covering latitudes from $11^{\circ} 55^{\prime} \mathrm{N}$ to $15^{\circ} 53^{\prime} \mathrm{N}$ (RAMACHANDRA et al., 2001). Unfortunately, today most of the original mother trees cannot be identified in field.

Flowering phenology was studied from April 1999 to August 1999 by tagging the known clones (Total 24 clones) and their ramets $(n=407)$. The site was visited at every one week interval to make observations on flowering phenophases like time of initiation and duration of flower bud, flowering and peak flowering. Scores were assigned as shown in Table 3. Further, average time of initiation and duration for budding, flowering and peak flowering were worked out (GuNAGA et al., 1999). In the study, infested/dead/mutilated trees were avoided while scoring. The time taken for commencement of flower buds, flowering and peak flowering were calculated as the number of days from $1^{\text {st }}$ January to the date of their first appearance on every tree. Duration of all phenophases was considered as total number of days of respective events. Peak flowering was defined as the time when approximately 75 per cent of the flowers on a tree are in bloom.

\subsection{Data analysis}

The data on each phenological phase were analysed as one way Analysis of Variance (ANOVA) by using MSTATC programme on a PC and the variability was decomposed into genetic and environmental components using the following model:

\begin{tabular}{|l|l|l|l|}
\hline Sl.no & \multicolumn{1}{|c|}{ Source } & \multicolumn{1}{c|}{ d.f. } & \multicolumn{1}{c|}{ Expected mean square } \\
\hline 1 & Between clones & $(\mathrm{c}-1)$ & $\sigma^{2}+\mathrm{n}_{0} \sigma_{\mathrm{C}}^{2}$ \\
\hline 2 & Error & $\sum\left(\mathrm{n}_{\mathrm{i}}-1\right)$ & $\sigma^{2}$ \\
\hline
\end{tabular}

Where,

$\mathrm{c}=$ number of clones

$\sigma^{2}=$ sum of squares due to error

$\sigma^{2}{ }_{c}=$ sum of squares due to clones (genotypic variance)

$\mathrm{n}_{0}=\Sigma \mathrm{n}_{\mathrm{i}}-\left\{\Sigma\left(\mathrm{n}_{\mathrm{i}}-1\right) / \mathrm{n}_{\mathrm{i}}\right\}$ as suggested by KEDHARNATH (1982) 


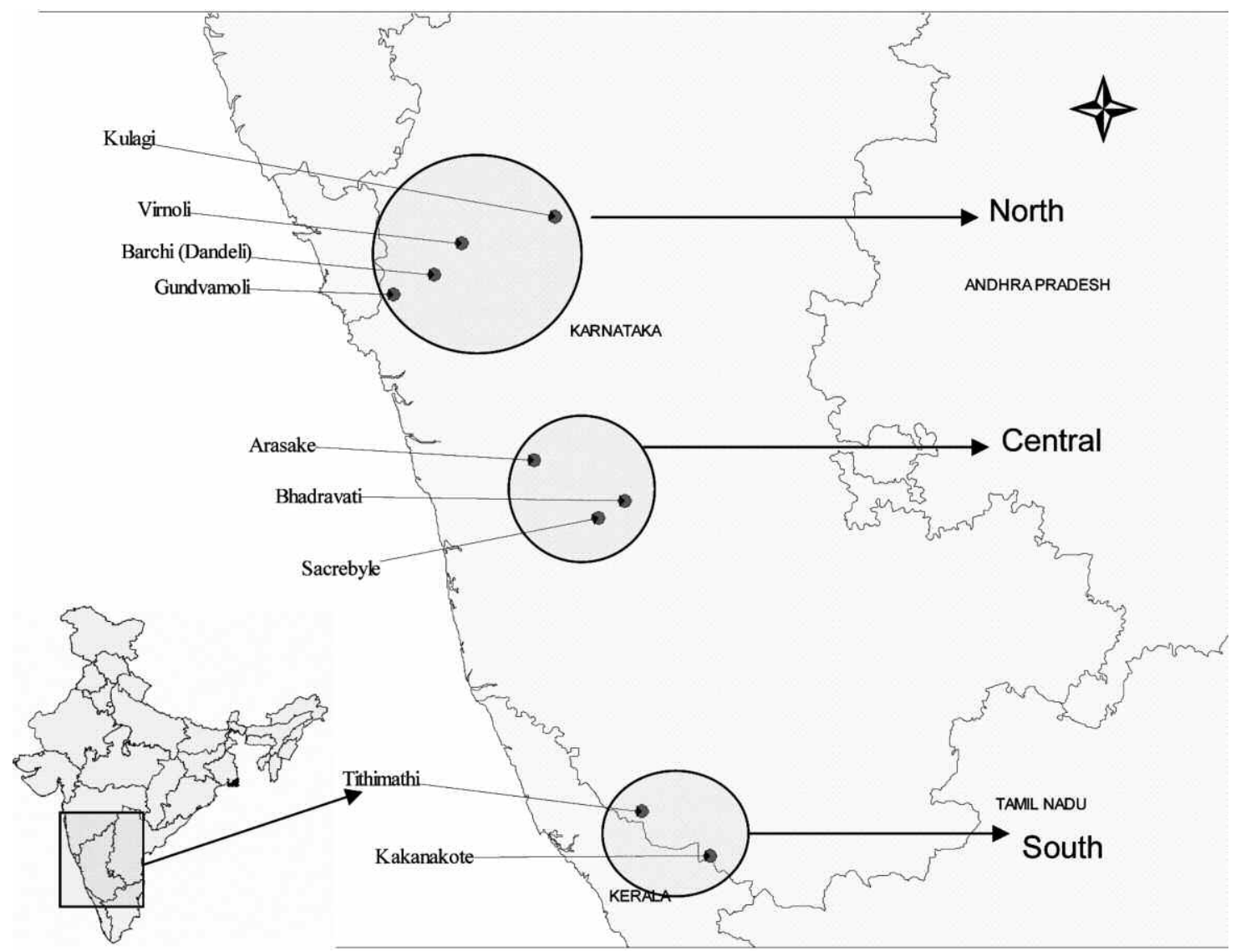

Figure 1. - Map showing the origin of plus trees from three geographic regions of Karnataka, India.

Table 3. - Table showing details of scores given for flowering phenological events.

\begin{tabular}{|l|l|c|}
\hline & Phenophases & Score \\
\hline 1 & Tree with no flower & 0 \\
\hline 2 & Bud initiation & 1 \\
\hline 3 & $0-25$ per cent flowers bloom & 2 \\
\hline 4 & $26-50$ per cent flowers bloom & 3 \\
\hline 5 & $51-75$ per cent flowers bloom & 4 \\
\hline 6 & More than 75 per cent & 5 \\
\hline
\end{tabular}

Since the number of ramets per clone differed, $\mathrm{n}_{0}$ was computed.

$\mathrm{n}_{\mathrm{i}} \quad=$ number of ramets of $\mathrm{i}^{\text {th }}$ clone.

Analyses of variance and computation of variance components were conducted on the data for each characteristic separately. The following simple linear model for the analysis of variance was adopted to test the effects of clones disregarding their geographic origin:

$$
\mathrm{Y}_{\mathrm{ik}}=\mu+\mathrm{c}_{\mathrm{k}}+\mathrm{e}_{\mathrm{ik}}
$$

Where $\mathrm{Y}_{\mathrm{ik}}$ is the performance of $\mathrm{i}^{\text {th }}$ ramet of $\mathrm{k}^{\text {th }}$ clone, $\mu=$ overall mean, $C_{k}$ is effect of $k^{\text {th }}$ clone and $e_{i k}$ is the random error associated with ramets. No test of significance of block effects was attempted since the orchard has been planted adopting completely randomized design.

In order to test the influence of 'geographic origin', a separate analysis was done wherein ramets were cate- gorized into three different groups viz., northern, central and southern based on their origin disregarding their clonal identity (see Table 1). Following simple linear model was adopted to test the influence of place of origin on various flowering phenological events:

$$
\mathrm{Y}_{\mathrm{ik}}=\mu+\mathrm{p}_{\mathrm{k}}+\mathrm{e}_{\mathrm{ik}}
$$

Where, $\mathrm{Y}_{\mathrm{ik}}$ is the performance of $\mathrm{i}^{\text {th }}$ ramet of $\mathrm{k}^{\text {th }}$ origin, $\mu=$ overall mean, $p_{k}$ is effect of $k^{\text {th }}$ origin (provenance) and $e_{i k}$ is the random error associated with ramets. The primary aim of these analyses was to test the influence of clone and place of origin on various flowering phenological events and not in the estimation of genetic parameters.

Following Gunaga and VASUdEva (2009), the overlap between two clones for their flowering period was computed based on the following formula adopted from the Morisita index of similarity (MORISITA, 1959) and Horn's index of similarity (HoRN, 1966). The time of peak flowering was used for analysis of overlap index.

$$
\operatorname{Overlap} \operatorname{Index}(C)=\frac{2 \sum_{\mathrm{i=i}}^{\mathrm{n}}\left(\mathbf{P}_{\mathrm{ij}} \times \mathbf{P}_{\mathrm{ik}}\right)}{\left(\sum \mathbf{P}^{2}{ }_{\mathrm{ij}}+\sum \mathbf{P}^{2}{ }_{\mathrm{ik}}\right)}
$$

Where,

$P_{i j}$ is the proportion of ramets of $j^{\text {th }}$ clone in peak flowering for a given period $i$,

$P_{i k}$ the proportion of ramets of $\mathrm{k}^{\text {th }}$ clone in peak flowering for a given period $i$, 
$n$ is the number of weeks in which the flowering observed,

$P_{i j} \times P_{i k}$ is the joint probability of flowering by two different clones.

The value of overlap index ranged from 0 (when there is no overlap between two clones) to 1 (when there is full overlap between two clones). Overlap indices of particular clone with all other individual clones was used to calculate the average overlap index of that clone.

\subsection{Genetic analysis}

For assessing the genetic dissimilarity among the teak clones planted in the orchard, DNA based ISSR markers were used. Leaf samples collected during July 2005 from the 24 clones were subjected to DNA extraction by following CTAB (Cetyl Trimethyl Ammonium Bromide) extraction method (Doyle and Doyle, 1987). DNA was quantified based on the spectrophotometric measurement of UV absorbance at optical density (OD) $260 \mathrm{~nm}$ and was diluted to working concentration (20 ng). Genetic analysis was carried out employing DNA based Inter Simple Sequence Repeat (ISSR) molecular markers. PCR amplification was carried out in a $15 \mu \mathrm{l}$ reaction mixture containing template DNA (20 ng), primer $(0.3 \mu \mathrm{M})$, Taq polymerase (0.5 units), $10 \times$ assay buffer and dNTPs $(1 \mathrm{mM})$. A total of 20 UBC-primers were screened, of which 10 primers (UBC 807, UBC 808, UBC 809, UBC 811, UBC 818, UBC 826, UBC 827, UBC 866, UBC 868, UBC 898) that gave consistent results and higher number of polymorphic bands was selected. Amplified PCR products were separated on a 1.5 per cent agarose gel stained with ethidium bromide
$(0.5 \mu \mathrm{g} / \mathrm{ml})$. The gel was visualized under a UV light and captured using Herolab Gel Documentation Unit. Binary coding was used to score the gels (WENDELL and WeEDEn, 1989). Presence of a PCR-amplified product was scored as 1 and its absence as 0 .

\subsection{Data analysis}

Based on the absence or presence of amplified products, Jaccard's dissimilarity index was computed by comparing all the possible pairs of clones $\left({ }^{n} C_{2}\right.$ pairs $)$ in the orchard.

The Jaccard dissimilarity for a pair of clones is calculated using the following formula;

$$
\mathrm{J}=\mathrm{M}_{01}+\mathrm{M}_{10} / \mathrm{M}_{01}+\mathrm{M}_{10}+\mathrm{M}_{11}
$$

where

$M_{11}$ represents the total number of amplicons shared by Clone 1 and Clone 2

$M_{01}$ represents the total number of amplicons where Clone 1 is 0 and Clone 2 is 1 .

$M_{10}$ represents the total number of amplicons where Clone 1 is 1 and Clone 2 is 0

$M_{00}$ represents the total number of amplicons Clone 1 and Clone 2 is 0.

Dissimilarity indices of a clone with all other individual clones in the orchard were used to calculate the average dissimilarity of that clone. Cluster analysis for the 24 clones in the orchard was constructed using Statistica Software ver. 7. At the regional level, clustering analysis was constructed using POPGENE ver. 2.

Table 4. - Clonal variation for time of flowering and peak flowering (both expressed as number of days from $1^{\text {st }}$ January 1999) and duration of flowering and peak flowering (number of days) in the clonal seed orchard of teak.

\begin{tabular}{|c|c|c|c|c|c|c|c|c|c|c|}
\hline \multirow{2}{*}{$\begin{array}{l}\text { Clone } \\
\text { I.D. }\end{array}$} & \multirow[b]{2}{*}{$\mathbf{N}$} & \multirow{2}{*}{$\begin{array}{c}\text { Geographic } \\
\text { Origin }\end{array}$} & \multicolumn{2}{|c|}{ Time of flowering initiation } & \multicolumn{2}{|c|}{ Peak flowering initiation } & \multicolumn{2}{|c|}{ Duration of flowering } & \multicolumn{2}{|c|}{ Duration Peak flowering } \\
\hline & & & Mean & \pm SD & Mean & \pm SD & Mean & \pm SD & Mean & \pm SD \\
\hline MyHaD1 & 22 & North & $192.91^{\mathrm{ab}}$ & 28.44 & $215.55^{\mathrm{ab}}$ & 16.83 & 42.05 & 17.64 & 15.86 & 5.33 \\
\hline $\mathrm{MyHaD2}$ & 29 & North & $203.10^{\mathrm{a}}$ & 10.82 & $222.72^{\mathrm{a}}$ & 11.21 & 49.14 & 14.80 & 17.27 & 8.75 \\
\hline $\mathrm{MyHaD} 3$ & 27 & North & $195.44^{\text {ab }}$ & 37.96 & $215.67^{\mathrm{ab}}$ & 11.35 & 54.48 & 15.85 & 12.51 & 7.35 \\
\hline $\mathrm{MyHaD} 4$ & 37 & North & $193.35^{\mathrm{ab}}$ & 12.56 & $217.59^{\mathrm{ab}}$ & 13.04 & 51.87 & 17.68 & 19.13 & 28.78 \\
\hline MyHaV1 & 12 & North & $147.42^{\mathrm{cd}}$ & 09.47 & $169.08^{\mathrm{d}}$ & 10.79 & 48.50 & 13.41 & 19.00 & 08.06 \\
\hline MyHaV3 & 16 & North & $153.06^{\mathrm{cd}}$ & 16.98 & $176.31^{\mathrm{d}}$ & 16.89 & 52.25 & 14.07 & 18.00 & 09.10 \\
\hline MyHaV4 & 8 & North & $183.63^{b}$ & 18.48 & $209.00^{\mathrm{bc}}$ & 12.90 & 54.13 & 12.56 & 14.87 & 04.02 \\
\hline MyHaV5 & 15 & North & $151.40^{\mathrm{cd}}$ & 13.39 & $175.07^{\mathrm{d}}$ & 12.16 & 54.67 & 10.47 & 16.80 & 09.34 \\
\hline MyHaV6 & 14 & North & $151.71^{\mathrm{cd}}$ & 11.43 & $179.93^{\mathrm{d}}$ & 12.03 & 50.21 & 13.36 & 13.14 & 06.85 \\
\hline MyHaV7 & 13 & North & $154.62^{\mathrm{cd}}$ & 11.51 & $180.85^{\mathrm{d}}$ & 13.61 & 59.23 & 16.46 & 15.84 & 11.54 \\
\hline MyHaK1 & 37 & North & $199.16^{\mathrm{a}}$ & 15.65 & $219.46^{\text {ab }}$ & 12.55 & 50.22 & 16.16 & 15.16 & 07.32 \\
\hline MyHaK2 & 26 & North & $196.35^{\mathrm{a}}$ & 12.78 & $215.73^{\text {ab }}$ & 08.34 & 54.92 & 18.19 & 17.07 & 06.28 \\
\hline MyHaK3 & 26 & North & $190.89^{\mathrm{ab}}$ & 14.49 & $214.77^{\mathrm{ab}}$ & 10.96 & 53.12 & 16.47 & 14.69 & 06.76 \\
\hline MySA1 & 11 & Central & $147.18^{\text {cd }}$ & 09.90 & $171.36^{\mathrm{d}}$ & 11.93 & 55.64 & 11.20 & 15.36 & 10.38 \\
\hline MySA2 & 15 & Central & $150.27^{\mathrm{cd}}$ & 14.69 & $180.53^{\mathrm{d}}$ & 16.83 & 57.20 & 13.12 & 15.66 & 07.48 \\
\hline MySS2 & 17 & Central & $147.88^{\mathrm{cd}}$ & 07.43 & $176.06^{\mathrm{d}}$ & 11.02 & 56.65 & 13.37 & 16.94 & 09.24 \\
\hline MyBL1 & 11 & Central & $143.46^{\mathrm{cd}}$ & 05.22 & $168.36^{\mathrm{d}}$ & 11.39 & 59.09 & 10.87 & 16.81 & 09.71 \\
\hline MyHuT1 & 10 & South & $153.80^{\mathrm{cd}}$ & 17.46 & $177.90^{\mathrm{d}}$ & 19.16 & 45.40 & 11.96 & 12.40 & 06.24 \\
\hline MyHuT2 & 15 & South & $149.33^{\mathrm{cd}}$ & 16.16 & $172.07^{\mathrm{d}}$ & 11.21 & 55.20 & 11.31 & 15.06 & 06.25 \\
\hline MyHuT3 & 6 & South & $147.50^{\mathrm{cd}}$ & 10.77 & $174.33^{\mathrm{d}}$ & 12.04 & 55.83 & 09.06 & 18.50 & 14.74 \\
\hline МyHuТ6 & 8 & South & $159.50^{c}$ & 21.63 & $198.88^{\mathrm{C}}$ & 32.88 & 54.13 & 07.70 & 17.50 & 14.04 \\
\hline MyHuT7 & 16 & South & $152.00^{\mathrm{cd}}$ & 11.87 & $176.81^{\mathrm{d}}$ & 13.96 & 59.75 & 11.05 & 17.93 & 06.69 \\
\hline MyHuT8 & 6 & South & $153.17^{\mathrm{cd}}$ & 13.11 & $175.50^{\mathrm{d}}$ & 15.19 & 47.17 & 08.86 & 18.50 & 07.92 \\
\hline MyMK3 & 10 & South & $151.50^{\mathrm{cd}}$ & 14.55 & $177.80^{\mathrm{d}}$ & 14.23 & 59.80 & 12.32 & 22.40 & 11.26 \\
\hline \multicolumn{3}{|c|}{$\mathrm{CSO}$} & 174.11 & 28.35 & 197.79 & 24.65 & 53.01 & 14.86 & 15.95 & 8.07 \\
\hline \multicolumn{3}{|c|}{ CD@5\% P } & \multicolumn{2}{|c|}{10.89} & \multicolumn{2}{|c|}{10.44} & \multicolumn{2}{|c|}{ NS } & \multicolumn{2}{|c|}{ NS } \\
\hline \multicolumn{3}{|c|}{ CV $(\%)$} & \multicolumn{2}{|c|}{8.11} & \multicolumn{2}{|c|}{6.84} & \multicolumn{2}{|c|}{27.80} & \multicolumn{2}{|c|}{50.49} \\
\hline
\end{tabular}

$\mathrm{N}$ : Number of ramets studied.

Mean values with same superscripts do not differ as shown by DuNCAN's Multiple Range Test. 
At the geographic origin level, the overlap indices of all pairs of clones from the same region were considered while calculating the average overlap index of clones for the particular region. The same procedure was adopted to calculate the average genetic dissimilarity index of clones originating from one region. Thereafter, t-test was used to ascertain the whether the differences in the average overlap index and average dissimilarity index among clones from three geographic regions were significant or not.

Table 5. - ANOVA table for time of flower initiation, duration of flowering, time of peak flower initiation and duration of peak flowering at clonal level and geographic region level.

\begin{tabular}{|c|c|c|c|c|c|c|c|c|c|c|c|c|c|}
\hline \multirow[t]{2}{*}{$\begin{array}{l}\text { Source of } \\
\text { Variation }\end{array}$} & \multirow[t]{2}{*}{ Df } & \multicolumn{3}{|c|}{$\begin{array}{l}\text { Time of flower } \\
\text { initiation }\end{array}$} & \multicolumn{3}{|c|}{$\begin{array}{l}\text { Duration of } \\
\text { flowering }\end{array}$} & \multicolumn{3}{|c|}{$\begin{array}{c}\text { Time of pak flower } \\
\text { initiation }\end{array}$} & \multicolumn{3}{|c|}{$\begin{array}{l}\text { Duration of peak } \\
\text { flowering }\end{array}$} \\
\hline & & MS & FV & $\mathbf{P}$ & MS & FV & $\mathbf{P}$ & MS & FV & $\mathbf{P}$ & MS & FV & $\mathbf{P}$ \\
\hline \multicolumn{14}{|c|}{ Clonal Level } \\
\hline Clones & 23 & 9184.5 & 46.1 & $<0.01$ & 328.3 & 1.51 & NS & 7672.82 & 41.9 & $<0.01$ & 69.2 & 1.069 & NS \\
\hline Error & 383 & 199.5 & & & 217.4 & & & 183.097 & & & 64.8 & & \\
\hline Total & 406 & & & & & & & & & & & & \\
\hline \multicolumn{14}{|c|}{$\begin{array}{l}\text { Geographic region } \\
\text { Level }\end{array}$} \\
\hline Region & 2 & $\begin{array}{r}52079 . \\
9\end{array}$ & 114.6 & $<0.01$ & 834.0 & 3.77 & 0.02 & 40084.8 & 97.3 & $<0.01$ & 80.6 & 1.241 & NS \\
\hline Error & 402 & 454.3 & & & 220.6 & & & 411.9 & & & 64.9 & & \\
\hline Total & 406 & & & & & & & & & & & & \\
\hline
\end{tabular}

$\mathrm{Df}=$ degrees of freedom; $\mathrm{MS}=$ mean sum of square $\mathrm{FV}=\mathrm{F}$ value $; \mathrm{P}=$ significance at Probability level; NS = Non-significant.

Table 6. - Variation for time of initiation of flowering and peak flowering (expressed as number of days from $1^{\text {st }}$ January 1999) and duration of flowering and peak flowering (number of days) in the Clonal Seed Orchard of teak as influenced by their geographic origin.

\begin{tabular}{|c|c|c|c|c|c|c|c|c|}
\hline \multirow{2}{*}{$\begin{array}{c}\text { Geographic } \\
\text { origin of } \\
\text { clones }\end{array}$} & \multicolumn{2}{|c|}{$\begin{array}{l}\text { Flowering } \\
\text { initiation }\end{array}$} & \multicolumn{2}{|c|}{$\begin{array}{c}\text { Peak flowering } \\
\text { initiation }\end{array}$} & \multicolumn{2}{|c|}{$\begin{array}{c}\text { Duration of } \\
\text { flowering }\end{array}$} & \multicolumn{2}{|c|}{$\begin{array}{l}\text { Duration of peak } \\
\text { flowering }\end{array}$} \\
\hline & Mean & $\pm \mathrm{SD}$ & Mean & $\pm \mathrm{SD}$ & Mean & $\pm \mathrm{SD}$ & Mean & $\pm \mathrm{SD}$ \\
\hline North & $184.78^{\mathrm{a}}$ & 24.04 & $207.11^{\mathrm{a}}$ & 21.78 & 51.79 & 15.89 & 15.57 & 7.56 \\
\hline Central & $147.50^{b}$ & 10.15 & $174.78^{b}$ & 13.55 & 57.09 & 12.11 & 16.24 & 8.9 \\
\hline South & $152.18^{b}$ & 15.05 & $178.27^{b}$ & 18.29 & 54.75 & 11.58 & 17.23 & 9.26 \\
\hline CD at $5 \% \mathrm{P}$ & \multicolumn{2}{|c|}{16.39} & \multicolumn{2}{|c|}{15.61} & \multicolumn{2}{|c|}{ NS } & \multicolumn{2}{|c|}{ NS } \\
\hline CV (\%) & \multicolumn{2}{|c|}{12.25} & \multicolumn{2}{|c|}{10.26} & \multicolumn{2}{|c|}{27.86} & \multicolumn{2}{|c|}{50.56} \\
\hline
\end{tabular}

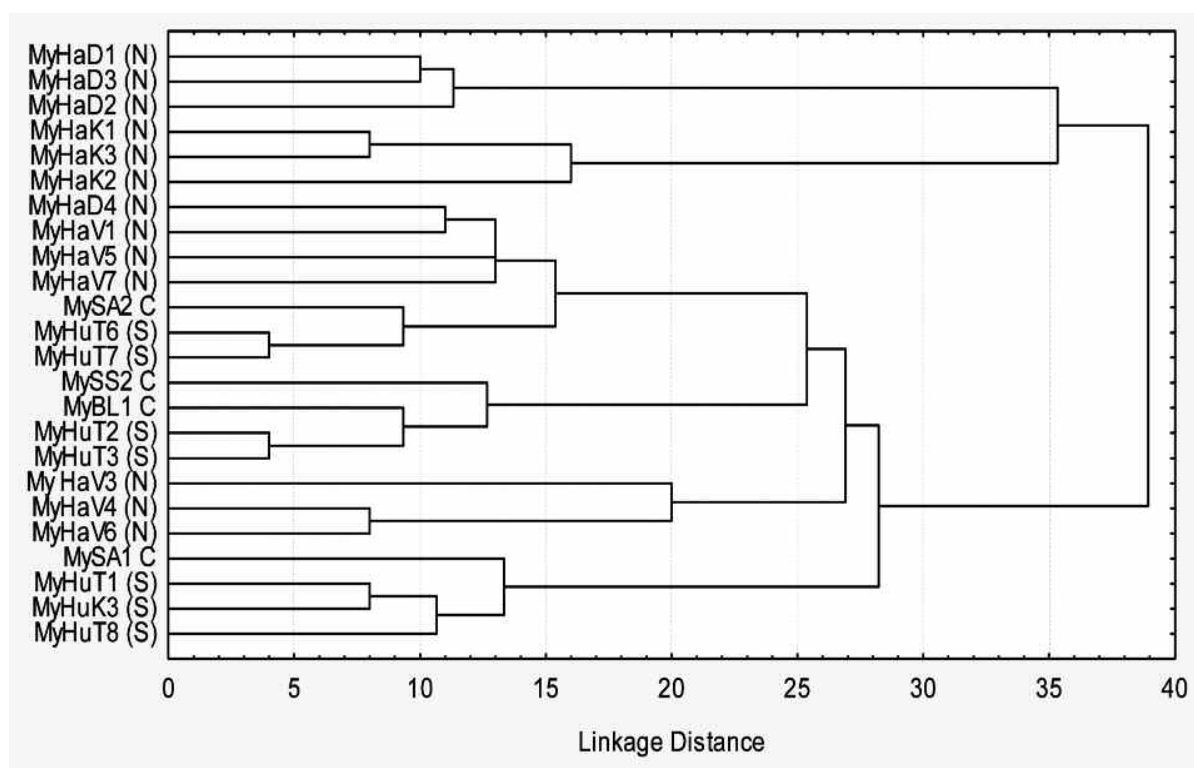

Figure 2. - Dendrogram (using squared Euclidean distance) for 24 teak clones in CSO at Manchikere, South India. 


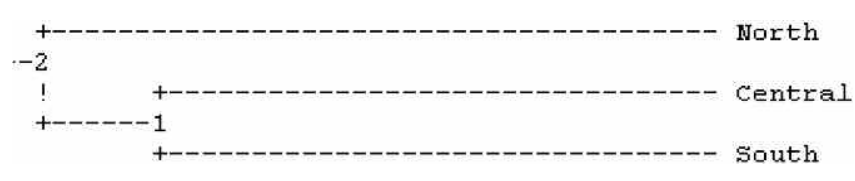

Figure 3. - Cluster analysis for 24 teak clones from three geographic regions (North, Central and South) in clonal seed orchard at Manchikere, South India.

\section{Results}

The values of co-efficient of variation suggested a limited variation for the initiation of flowering and peak flowering and moderately larger variations for duration of these phenophases (Table 4). However, time of flower initiation and peak flowering period among 24 teak clones was found to be significantly different $(F=46.1$, $\mathrm{p}<0.01 ; F=41.9, \mathrm{p}<0.01$, respectively; Table 5$)$. The average number of days to flowering initiation and peak flowering initiation, computed as number of days from 1st January ranged from 143.46 and 168.36 to 203.1 and 222.72 for clone MyBL1 and MyHaD2, respectively (Table 4). However, the duration of flowering and duration of peak flowering among clones did not differ significantly (Table 5) with an average of 53.01 14.86 and $15.95 \pm 8.07$ days, respectively (Table 4). The overlap index as a degree of synchrony among two sets of clones ranged from 0.382 (MyHuT2 with MyHaD2) to 0.99 (MySA1with MyHuK3). Highest average overlap index of a clone with rest of clones in the orchard was noted for clone MyHuT6 (0.890) and lowest for clone MyHaD2 (0.639).

Significant influence of geographic origin on three floral phenophases was also observed during the study
(Table 6). Teak clones originating from central and southern regions tended to initiate flowering as well as peak flowering significantly earlier to those from northern region (Table 6).

Dissimilarity index between clones in the orchard was calculated based on 95 amplicons generated using 10 ISSR primers. The average dissimilarity index between clones in the orchard was found to be $0.147 \pm 0.036$. The dendrogram generated for 24 clones revealed two clusters; the major cluster comprising of clones from all regions, while the minor cluster solely of clone of northern origin (Fig. 2). Clustering of clones grouped according to their region of origin showed a close association between the central and southern group (Fig. 3).

A significant negative association $(\mathrm{r}=-0.4759, \mathrm{df}=22$, $\mathrm{p}<0.05$; Fig. 4) was observed between average genetic dissimilarity of a clone with rest of the clones of the orchard (as computed by the Jaccard's index) and the overlap index (which summarily characterizes level of flowering synchrony of a clone with the rest of the clones in an orchard). This clearly suggests that clone with a larger genetic dissimilarity tend to have lower overlap in its peak flowering with other clones of the orchard. A similar general trend was also observed when the data was recast based on the geographic origin of the clones (Table 7). As a group, the clones belonging to northern region had relatively higher genetic dissimilarity with rest of the clones and consequently showed lower values for average peak flowering overlap index. While the clones belonging to southern regions showed less values for Jaccards index and a higher overlap. However this trend was not true in case of clones belonging to the central region.

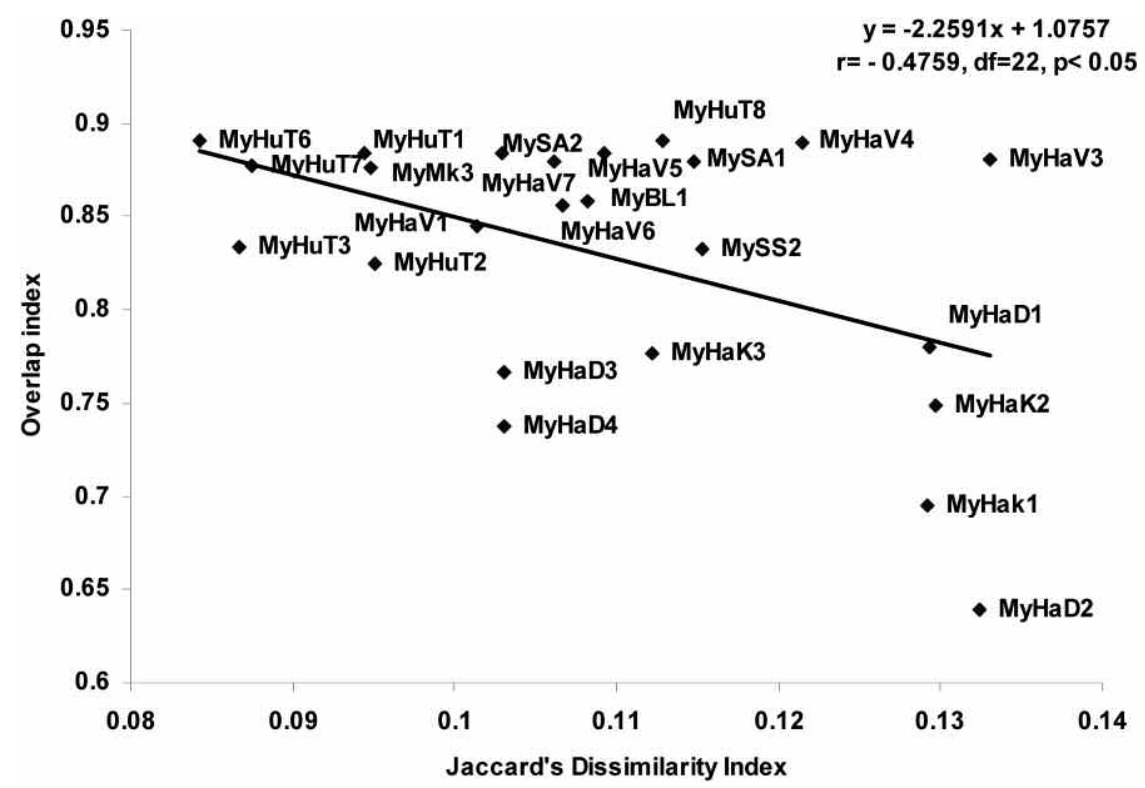

Figure 4. - Association between Jaccard's Dissimilarity index computed based on ISSR markers and phenological overlap index.

Each point represents a clone [The genetic dissimilarity of a clone is the average of dissimilarity indices with all the other clones (except itself). Similarly, the overlap index of clone represents the average of the overlap indices with all other clones (except itself). With the increase in average dissimilarity of a clone, the phenological overlap also decreases]. 
Table 7. - Average peak flowering overlap index and average Jaccard's Dissimilarity index of clones from three geographic origins.

\begin{tabular}{|l|l|l|l|}
\hline $\begin{array}{l}\text { Geographic } \\
\text { origin }\end{array}$ & Number of clones & $\begin{array}{l}\text { Average Peak Flowering } \\
\text { Overlap Index }\end{array}$ & $\begin{array}{l}\text { Average Jaccard's } \\
\text { Dissimilarity Index }\end{array}$ \\
\hline Northern & 13 & $0.808 \pm 0.175^{\mathrm{a}}$ & $0.124 \pm 0.027^{\mathrm{a}}$ \\
\hline Central & 4 & $0.979 \pm 0.008^{\mathrm{b}}$ & $0.119 \pm 0.023^{\mathrm{a}}$ \\
\hline Southern & 7 & $0.961 \pm 0.010^{\mathrm{c}}$ & $0.060 \pm 0.017^{\mathrm{b}}$ \\
\hline Pooled & 24 & $0.829 \pm 0.174$ & $0.113 \pm 0.029$ \\
\hline
\end{tabular}

** Different alphabets indicate t-test significance level at $95 \%$ confidence level.

\section{Discussion}

Flowering asynchrony in clonal seed orchards have been extensively documented in teak (ANMOL KUMAR, 1992; RAWAT et al., 1992; PALUPI and OWENS, 1998; GunAGA et al., 1999; GunAGA and VASUdEva, 2009) as well as in other species (GRIFFIN, 1984 in Radiata pine; Askew, 1986 in loblolly pine; EL-KaSsABY and ASKEW, 1991 in Douglas fir; MATZIRIS, 1994 in Black pine and VERMA et al., 1989 in Eucalyptus citriodora). Clones from geographically diverse origin are known to differ in their reproductive phenology when grown in an orchard (MATZIRIS, 1994) and has been earlier reported in teak (VASUdEva et al., 2000). Consequently, subsets of synchronized clones originating from the same region, which may be more related, can give rise to subpopulation structure within the orchard (EL-KASSABY, 1989).

Interestingly, clones from Barchi (MyHaD1, MyHaD2, MyHaD3, MyHaD4) and Kulagi (MyHaK1, MyHaK2, MyHaK3) origin of northern region had highly similar flowering initiation period and peak flowering period (Table 4) as well as showed higher levels of genetic similarity among themselves as assessed through ISSR markers and shown in the dendrogram (Fig. 2). It is expected that tree to tree variation for phenological patterns in a population would be less because phenological patterns are shaped as a response to common climatic cues by the entire population through natural selection. However provenance differences for this trait would be larger. Our study also supports this notion since genetically similar populations showed higher synchrony (Table 7). Earlier GunAGA and VASUDEVA (2002) have reported two separate peaks in flowering, one referring to teak clones of northern region and the other to clones of southern and central origin which can be attributed to those populations being genetically more similar as evident from the dendrogram (Fig. 3). As a consequence, there is higher chance of mating between genetically similar clones or provenances with synchronous flowering behaviour within the orchard.

Clonal as well as provenance asynchrony in flowering phenology is expected to have huge limitation to achieve the goals of an orchard where traditionally unrelated clones are used for orchard establishment to avoid inbreeding depression. LINDGREN et al. (1997) suggested that 200 unrelated parents is a reasonable number to achieve gain when considering the costs and benefits of breeding. However, as a cautionary measure, it is neces- sary to include plus-trees in the natural populations of the same breeding zone, where ecological conditions are quite similar and genetic parameters have high values. Following these requirements each seed orchard may be dedicated to produce genetic material for one or few neighbouring breeding zones with no dramatic environmental differences.

Assembling unrelated clones or clones from wide geographic origin (provenances) may result in high flowering asynchrony in the orchard due to the genetic dissimilarity of clones obtained from different region. We validated this assumption by calculating the average Jaccards' dissimilarity index and average peak flowering index of each clone and demonstrating the negative association between these two. This is perhaps the first reported evidence on the problem associated with maintaining high genetic dissimilarity between clones in a clonal seed orchard of forest trees. The constituent clones of Manchikere CSO where the study was conducted originate from diverse climatic regions from drier southern region to wetter part of northern region (Table 2).

Besides the main objective of obtaining high quality out-crossed seeds from a clonal orchard, ensuring a broad genetic base within the orchard population is essential for future improvement programmes. However, results of this study have indicated that maintaining a very broad genetic base by planting highly dissimilar clones in clonal seed orchards of teak may run contradictory to the main objective of a CSO. By assembling highly dissimilar clones or clones from distinct provenances in the orchard, random mating is constrained by their difference in flowering patterns. As a result, mating of closely related clones or clones within a provenance with similar flowering patterns may cause larger number of empty or selfed seeds to be harvested from the orchard a direct impact on the orchard's reproductive success. Therefore, a compromise between these two components may be a prerequisite for ensuring high reproductive success of populations as well as maintaining an ideal genetic base. This becomes essentially important in clonal seed orchard establishment wherein clones from different geographic regions are assembled. Over the years, teak clonal seed orchards have been established with the aim of encouraging out-crossing rates between clones from diverse origin with little importance given to the flowering behaviour between those clones. Perhaps 
this practice could well be one of the factors responsible for low quality of seed obtained from orchard populations and has prompted large-scale planters to abandon the seed orchard concept considered useful about 30 years ago when they were established (GoH et al., 2003).

\section{Acknowledgements}

Director, Group Coordinator, (Research) and Head of Department, TIP Division, IWST, Bangalore for the facilities provided. Council for Scientific and Industrial Research (CSIR) for providing scholarship to NICOLEE LYNGDOH as well as Karnataka Forest Department for providing funding for a Research Project to R. VASUDEvA is greatly acknowledged. Assistance and field support was provided by research wing of Karnataka Forest Department.

\section{References}

Alizoti, P. G., K. Kilimis and P. Gallios (2010): Temporal and spatial variation of flowering among Pinus nigra Arn. Clones under changing climatic conditions. For. Ecol. and Mgt. 259: 786-797.

ANDERSson, E. (1960): Froplantagen I Skogsbrukets Tjanst [Seed orchards in Swedish Forestry] Satryck ur Kungl. Skogs-och Lantbruksaadememiens Tidskrift. 99, 65-87.

ANMOL KUMAR (1992): Teak seed improvement-achievement and problems. Indian Forester 116, 525-533.

Askew, G. R. (1986): Implication of non-synchronous flowering in clonal seed orchards. IUFRO Conference on a Joint meeting of working parties on breeding theory, progeny testing and seed orchards, Williamsburg, Virginia, pp, 182-191.

Askew, G. R. (1988): Estimation of gamete pool composition in clonal seed orchards. Silvae Genetica 37, 227-232.

Askew, G. R. and T. D. Blush (1990): An index of phonological overlap in flowering for clonal conifer seed orchards. Short note. Silvae Genetica 39 (3-4), 168-171.

Chaix, G., P. Vigneron, V. Razafimaharo and S. Hamon (2007): Are phenological observations sufficient to estimate the quality of seed crops from a Eucalyptus grandis open-pollinated seed orchard? Consequences for seed collections. New Forests 33, 41-52.

Doyle, J. J. and J. S. DoyLE (1987): A rapid DNA isolation procedure for small quantities of fresh tissues. Phytochemical Bulletin 19, 11-15.

El Kassaby, Y. A., K. Ritland, A. M. Fashler and W. J. DEVITT (1988): The role of reproductive phenology upon the mating system of a Douglas-fir seed orchard. Silvae Genetica 37(2), 76-82.

EL Kassaby, Y. A. (1989): Genetics of Douglas-fir seed orchards: expectations and realities. In $20^{\text {th }}$ Biennial Southern Forest Tree Improvement Conference on June 26-30, 1989 in Charleston, SC pp, 87-109.

El Kassaby, Y. A. and S. ReYnoldS (1990): Reproductive phenology, parental balance and supplemental mass pollination in a Sitka spruce seed orchard. Forest Ecology and Management 31, 45-54.

El-Kassaby, Y. and G. R. Askew (1991): The relation between reproductive phenology and reproductive output in determing the potential gametic pool profile in a Douglas-fir seed orchard. Forest Science 37(3), 827-835.
ERIKsson, G., A. Jonsson and D. LINDGREN (1973): Flowering in a clone trial of Picea abies. Studia Forestalia Suecica, 110 , pp. 45 .

Goh, D. K. S., D. Alloysius, J. Gidiman, H. H. Chan, B. MAllet and O. MonteuUis (2003): Selection and propagation of superior teak plant material for improved quality plantation establishment: the ICSB/Cirad-Foret's joint project as a case study. International Conference on Quality Timber Products of Teak from Sustainable Forest Management, Kerala Forest Research Institute, Peechi, pp. 281-291.

GRIFFIN, A. R. (1984): Clonal variation in radiata pine seed orchards. 2. Flowering phenology. Australian Forest Research 14, 271-281.

Gunaga, R. P., R. Vasudeva, M. Hanumantha and M. H. SWAMINATH (1999): Blooming variation among clones of different provenances in teak. My Forest 35(3), 237-247.

GuNAGA, R. P. and R. VASUdEVA (2002): Variation in flowering phenology in a clonal seed orchard of teak. Journal of Tree Sciences 21, 1-10.

Gunaga, R. P. and R. VASudeva (2008): Overlap index: a measure to assess flowering synchrony among teak (Tectona grandis Linn. f) clones in seed orchards. Current Science 97(6), 941-946.

HoRN, H. S. (1966): Measurement of overlap in comparative ecological studies. Am. Nat. 100, 419-424.

Jonsson, A., J. EkBERG and G. ERIKSsON (1976): Flowering in a seed orchard of Pinus sylvestris. Studia Forestalia Suecica, 135, pp.38.

KEDHARNATH, S. (1982): Genetic variation and heritability of juvenile height growth in Eucalyptus grandis. Journal of Tree Sciences 6, 44-49.

LINDGREN, D., R. P. WEI and S. J. LEE (1997): How to calculate optimum family number when starting a breeding program. Forest Science 43, 206-212.

LyNGDOH, N. (2010): Assessing the genetic dynamics of natural and improved populations of teak (Tectona grandis Linn. f.) in Karnataka. PhD Thesis submitted to FRI, Dehra Dun, pp. 215.

MATZIRIS, D. I. (1994): Genetic variation in the phenology of flowering in Black pine. Silvae Genetica 43, 321-328.

MoRIsitA, M. (1959): Measuring inter-specific association and similarity between communities. Mem. Fac. Sci. Kayushu Univ. Ser. (Biol.) 3, 65-80.

NikKanen, T. (2001): Reproductive Phenology in a Norway Spruce Seed Orchard. Silva Fennica 35(1), 39-53.

PALUPI, E. R. and J. N. OwEns (1998): Reproductive phenology and reproductive success of teak (Tectona grandis L.f.). Int J Plant Sci 159, 833-842.

Radhamani, A., A. Nicodemus, B. Nagarajan and A. K. MANDAL (1998): Reproductive biology of tropical tree species. In: MANDAL, A. K., GiBson, G. L. (Eds). Forest Genetics and Tree Breeding. CBS-Publishers and Distributors, New Delhi, p. 268.

RamanchandRa, Vijay Sharma, T. V. Mohandas, J. N. RAJ, K. M. Vittal, Subkath Hussain and V. P. Hiremath (2001): Forestry Research in Karnataka. Karnataka Forestry Department, Bangalore, India, Pp. 1-138.

RAWAT, M. S., D. P. UNIYAL and R. K. VAKShasYa (1992): Variation studies in the model teak seed orchard, New Forest, Dehra Dun. Indian Forester 118, 60-65.

Reilly, C. O., W. H. PARKer and J. E. BARKer (1982): Effect of pollination period and strobili number on random mating in a clonal seed orchard of Picea mariana. Silvae Genetica 31 (2-3), 90-94. 